\title{
Short Communication: Evaluation of water quality and survival rate of red tilapia (Oreochromis niloticus) by using rice-fish culture system in quarry land of clay
}

\author{
DEWI HIDAYATI ${ }^{1, \vartheta}$, SUPIANA DIAN NURTJAHYANI ${ }^{2}$, DWI OKTAFITRIA ${ }^{2}$, NOVA MAULIDINA ASHURI ${ }^{1}$, \\ WAHYU KURNIALLAH ${ }^{1}$ \\ ${ }^{1}$ Department of Biology, Faculty of Science, Institut Teknologi Sepuluh Nopember. J1. Raya ITS, Keputih, Sukolilo, Surabaya 60111, East Java, \\ Indonesia. "email: dewi_hidayati@ymail.com. \\ ${ }^{2}$ Universitas PGRI Ronggolawe Tuban. Jl. Manunggal No. 61, Gedongombo, Semanding, Wire, Tuban 62381, East Java, Indonesia
}

Manuscript received: 27 October 2018. Revision accepted: 31 January 2019.

\begin{abstract}
Hidayati D, Nurtjahyani SD, Oktafitria D, Ashuri NM, Kurniallah W. 2019. Short Communication: Evaluation of water quality and survival rate of red tilapia (Oreochromis niloticus) by using rice-fish culture system in quarry land of clay. Biodiversitas 20: 589594. Quarry land is an area that has been used as mining land and has different characteristics from the former conditions before being mined so that the level of productivity of the soil decreases. This study aims to determine the suitability of clay quarry land in Tuban as a cultivation medium based on the analysis of the water quality and survival rate of red tilapia (Oreochromis niloticus) using rice-fish culture system. This study used a completely randomized experimental design method with triplicate of three ratio of cultivation medium using Ex-mining Land Soil (EmLS) from quarry land and Top Soil, i.e., 1:0 (A), 1:1 (B), and 0:1 (C/Control). Results of water quality measurements that include nitrite, nitrate, temperature, $\mathrm{pH}$, and dissolved oxygen in descriptive unreal influence showed good condition. However, ammonia gives a significantly different effect mainly on the survival rate in 30 days nurture. In the end, the ANOVA test result of tilapia survival in treatment $A$ was not significantly different $(P>0.05)$ with treatment $B$ and control. B ased on these data, it can be seen that the EmLS from the quarry land of clay and TS can be used as a medium for cultivation of red tilapia $(O$. niloticus) with the recommended ratio of 1:1.
\end{abstract}

Keywords: Clay, Oreochromis niloticus, quarry land, rice-fish culture system, survival rate

\section{INTRODUCTION}

The Tlogowaru clay quarry area in Tuban, before being mined was rice fields and was planted with corn trees. In general, it was owned by the community which was then purchased by PT. Semen Indonesia (Persero) Tbk (Parascita et al. 2015). After mining activities were finished the quarry land has become a water catchment pond. The rainfall and the seepage of water from surrounding fractures land make the basins containing water on the surface of the quarry lands (Nwachukwu et al. 2018). One of the main problems of clay mining is the inefficient use of post-mining land that is no longer productive, for example, the lack of reclamation and rehabilitation of postproduction land (Peshkova et al. 2016). However, there are several examples of ex-mining land that have been reported to be useful i.e. reforesting 12 hectares of clay mines in Costa Rica and Sitapuram quarry of limestone located in India Southeast of turning the pit into a lake, including a small pond and reservoir bowl which can be used for agricultural irrigation and fish farming (WBCSD 2011).

The post-mining clay in Tuban needs further management so that the benefits of the community can be achieved. One of the suggested efforts is to conduct activities based on the potential of the region, i.e. the abundance of water from quarry land and agricultural activities by the community. Therefore, a potential activity to do is the Rice-Fish Culture System (RFCS). Rice-Fish Culture System is the nurture of rice and fish simultaneously and the best choice to increase food production from limited land through ecological agriculture (Tsuruta 2011). The types of fish that are cultivated with the rice-fish system are mostly tilapia (Lantarsi, 2016).

Based on this, it is necessary to know the impact of using Ex-mining Land Soil on water quality as cultivation medium and the survival of the fish which are cultivated using the rice-fish culture system, because water is one of the most essential factors for fish culture so that, based on these results, it is expected to be the basis for the utilization of the area around the clay mining land so that its land use is increasing.

\section{MATERIALS AND METHODS}

\section{Study area}

This research was conducted in July-August 2018 by making a miniature plot of rice fields in the greenbelt area where former clay mining was located in Temandang Village, Merakurak Subdistrict, Tuban District, East Java, 
Indonesia and the Zoology and Animal Engineering Laboratory, Department of Biology, Faculty of Sciences, Institut Teknologi Sepuluh November, Surabaya, Indonesia.

\section{Procedures}

Experimental design

The experimental design used in this study was a completely randomized design (CRD) with triplicate of three ratios. The treatments in the study were the differences in the ratio of land use i.e comparison of Exmining Land Soil (taken from quarry land) and Top Soil as medium in the rice-fish culture system, i.e. treatment of $\mathrm{A}=$ $1: 0 ; \mathrm{B}=1: 1 ;$ and $\mathrm{C}=0: 1$ (Control). The land preparation phase began with the creation of pond design ( $4 \times 3$ meter). The pond that has been finished was then installed with a tarpaulin on the bund and the bottom of the pond, after which the pond was filled with soil medium according to each treatment. After the soil was treated with fertilizing method, then it was made as a place for fish to live with a width of $75 \mathrm{~cm}$ from the bund. After that, the rice was planted and one week later tilapia was released into this Rice-Fish Culture System pond.

\section{Nurture of fish culture}

This study used a strain of Larasati red tilapia (Oreochromis niloticus) obtained from juvenile traders in Tuban with average size of $6.5 \mathrm{~cm}$ and a weight average of 9.12 gram which was then released into a pond with volume of $50 \mathrm{fish} / \mathrm{pond}$. The feed used in this study was artificial feed (CP Prima T 78-2 contains $25-27 \%$ protein). Feeding was carried out with the restricted feed method which was $5 \%$ of the total weight of the fish with the frequency of feeding of twice a day, i.e. 08.00 and 16.00 WIB. Fish are kept for 40 days and data sampling was done every 10 days.

\section{Chemical parameters and fish survival}

Water quality parameters measured in situ are temperature (digital thermometer), Dissolved Oxygen (Lutron PDO-519), pH (pH-ATC 211R), and ex situ are ammonia, nitrite, and nitrate (Genesys 10S UV-Vis Spectrophotometer), then the measured biological parameter is the survival rate of tilapia red (O. niloticus) using the Goddard (1996) method:

$$
S R=\frac{N t}{N o} \times 100 \%
$$

Where:

SR: Survival Rate (\%)

$\mathrm{Nt}$ : number of living tilapia at the end of the study (tail)

No: Number of tilapia at the beginning of the study (tail)

\section{Data analysis}

The data were analyzed statistically using diversity analysis or $f$ test (ANOVA) to determine the effect of treatment (independent variables) on the response parameters measured (test $f$ ). If the test value $f$ is significantly different or very much different, then the Smallest Significant Difference test (SSD) is carried out to determine the difference in effect between treatments.

\section{RESULTS AND DISCUSSION}

\section{Water quality}

Management of water quality is one of the influencing factors of success in cultivation activities. Based on Table 1, all parameters of water quality are still at the optimal level except ammonia which slightly exceeds the optimal limit for tilapia aquaculture. Water quality parameters such as temperature, Dissolved oxygen (DO), $\mathrm{pH}$, ammonia, nitrite, and nitrate during the red Tilapia culture are shown in Table 1.

\section{Temperature}

Temperature is a physical factor that is very important in water quality because it has an influence on other water quality parameters and directly affects the life of aquatic organisms. In situ measurement results showed temperature range, i.e. 23.2-26.8 ${ }^{\circ} \mathrm{C}$ in the morning while 28.7$32.3{ }^{\circ} \mathrm{C}$ in the afternoon (Figure 1) with the lowest temperature is obtained in treatment $\mathrm{C}$ (morning) and $\mathrm{B}$ (afternoon) while the maximum temperature is obtained in treatment B (morning) and A (afternoon). The value of the temperature obtained from each measurement has no significantly different from each other treatment and tends to be stable, but the treatment $\mathrm{C}$ as a control has a slightly lower temperature value than that in treatment $\mathrm{A}$ and $\mathrm{B}$. Based on the optimal temperature range for tilapia fish nurture in accordance with El-Sayed and Kawanna (2008) which is $24-32{ }^{\circ} \mathrm{C}$, the temperature in each treatment supports the life of tilapia.

There is an increase in measurement of morning temperature to afternoon temperature (Figure1), this is due to the presence an increase in the intensity of sunlight shining down the pond, but the temperature increase is not over $10{ }^{\circ} \mathrm{C}$ so that it is still safe for the fish. The increasing water temperature of $10^{\circ} \mathrm{C}$ will cause an increase in oxygen consumption of aquatic organisms. If there is an increase in temperature, it will reduce the dissolved oxygen concentration and to some extent cannot meet the oxygen demand for metabolic processes and respiration (Clarke and Johnston 1999). Since the RFCS was designed as the shallow pond, the differences of pond's temperature between morning and afternoon possibly occur. Abbasi et al. (2016) reported if there are several factors that result the temperature of shallow pond is unstable. The shallow pond can respond faster to air heating, wind speed and direction, the exposure to solar radiation and air humidity. Increasing water temperature to a certain extent can stimulate fish metabolism and increase the rate of feed consumption so as to accelerate growth (Kausar and Salim, 2006). 
Table 1. The range of water quality parameters during culture period of Red tilapia in rice-fish culture system

\begin{tabular}{|c|c|c|c|c|c|c|}
\hline \multicolumn{2}{|c|}{ Parameter } & \multirow[t]{2}{*}{ Unit } & \multicolumn{3}{|c|}{ Treatment } & \multirow[t]{2}{*}{ Optimal range } \\
\hline & & & $\mathbf{A}$ & B & $\mathbf{C}$ & \\
\hline \multirow[t]{2}{*}{ Temperature } & Morning & ${ }^{\circ} \mathrm{C}$ & $23.3-26.6$ & $23.2-26.8$ & $23.3-26.3$ & $25-32^{a}$ \\
\hline & Afternoon & & $31.2-32.1$ & $31.1-32.3$ & $28.7-30.7$ & \\
\hline \multirow[t]{2}{*}{ Dissolved Oxygen } & Morning & $\mathrm{mg} / \mathrm{L}$ & $3.2-4.1$ & $3.3-4.6$ & $3.6-4.7$ & $\geq 3^{\mathrm{a}}$ \\
\hline & Afternoon & & $5.4-6.2$ & $5.4-6.3$ & $5.7-6.4$ & \\
\hline $\mathrm{pH}$ & & - & $7.65-7.72$ & $7.52-7.65$ & $7.41-7.68$ & $6.5-8.5^{\mathrm{a}}$ \\
\hline Ammonia & & $\mathrm{mg} / \mathrm{L}$ & $0.085-0.2001$ & $0.0927-0.1538$ & $0.0791-0.133$ & $\leq 0.1^{\mathrm{b}}$ \\
\hline Nitrite & & $\mathrm{mg} / \mathrm{L}$ & $0.0033-0.025$ & $0.0036-0.0349$ & $0.0018-0.0176$ & $0.02-0.12^{c}$ \\
\hline Nitrate & & $\mathrm{mg} / \mathrm{L}$ & $0.1195-0.3524$ & $0.1431-0.409$ & $0.1577-0.4896$ & $0.2-219^{c}$ \\
\hline
\end{tabular}

Note: ${ }^{\text {a) }}$ SNI 7550:2009; ${ }^{\text {b) }}$ El-Sayeed (2006); ${ }^{\text {c) }}$ Setiadi et al. (2018)

\section{Dissolved oxygen}

Oxygen is one of the important limiting factors so if its availability in water does not meet the needs of cultivation biota, then all biota activities will be hampered (Swann 1997; Lucas 2018). The results of in-situ measurement of dissolved oxygen range $3.2-4.7 \mathrm{mg} / \mathrm{L}$ in the morning and 5.4-6.4 mg/L in the afternoon (Figure 1) with the lowest value is in treatment $\mathrm{A}$ (morning) and $\mathrm{B}$ (afternoon) while the highest temperature is in treatment $\mathrm{C}$ in the morning and in the afternoon. Lower dissolved oxygen in the morning is caused by the use of oxygen by rice plants and phytoplankton for respiration at night. Jean-Renaud et al. (2016) stated that the respiration of animals and plants causes anoxic or fewer oxygen conditions that occur at night until before dawn.

The obtained value of dissolved oxygen from each measurement has no significantly different from each other treatment and is above the oxygen tolerance limit dissolved in the nurture of tilapia i.e. $\geq 3 \mathrm{mg} / \mathrm{L}$ (Lucas et al. 2018). In the rice-fish culture system pond, the main inorganic nitrogen can be dissolved in water, i.e. ammonia, ammonium, nitrite, and nitrate. The composition of inorganic nitrogen is strongly influenced by the free oxygen content in water. The low oxygen concentration causes nitrogen to move towards the ammonia compound, while the highest oxygen concentration causes nitrogen to move towards the nitrate compound (Hutagalung and Rozak 1997). In addition, dissolved oxygen levels in the nurture pond also important for the nitrification process (Hargreaves and Tucker 2004).
pH

The ability of water to bind or release a number of hydrogen ions will indicate whether the solution is acidic or alkaline. The obtained $\mathrm{pH}$ value fluctuated in every 10 days of measurement, but the value still ranged from 7.417.72 with the lowest value is in the treatment $C$ whereas the highest value is in treatment A (Figure 1). Based on these results, the $\mathrm{pH}$ value is still present in the optimal range of tilapia nurture ponds, i.e. 6.5-8.5 (Lucas et al. 2018). ElSherif and El-Feky (2009) observed that water with pH 7-8 could be more suitable for tilapia culture for optimum growth performance and survival rate. Changes in $\mathrm{pH}$ values can also be caused by carbon dioxide concentration in the waters. The more $\mathrm{CO}_{2}$ produced from respiration, the reaction moves to the right and gradually releases the $\mathrm{H}^{+}$ ion which causes the $\mathrm{pH}$ of the water to lessen.

Ex-mining Land Soil in Tuban has a higher $\mathrm{pH}$ value (6.6-6.9) than Top Soil (5.8-6.3) due to the texture of both. EmLS is dominated by sand particles while TS contains more clay. According to statement of Boyd et al. (2002), the particles of clay and organic matter in soil are negatively charged hence attract cations toward their surfaces. The pond bottom with the clay content showed low $\mathrm{pH}$. Meanwhile, the limestone content in the soil can neutralize the soil acidity, hence limestone often uses for adjusting $\mathrm{pH}$ in aquaculture ponds that have acidic bottom soils and low alkalinity water. Accordingly, the physical factors and soil composition of sediment influences the $\mathrm{pH}$ and affect the distribution of microorganisms whose metabolism depends on the distribution of these chemical factors.

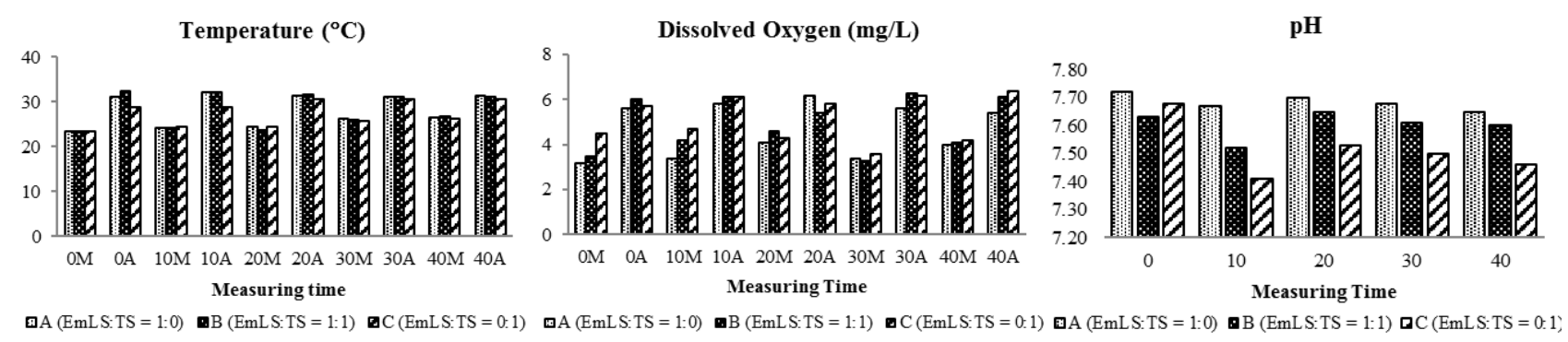

Figure 1. The average value of the RFCs nurture pond during the observation period $(\mathrm{EmLS}=\mathrm{Ex}-\mathrm{mining}$ Land Soil and TS= Top Soil) 


\section{Ammonia}

Free ammonia cannot be ionized, while ammonium $\left(\mathrm{NH}_{4}{ }^{+}\right)$can be ionized. Non-ionized free ammonia $\left(\mathrm{NH}_{3}\right)$ is toxic to aquatic organisms. High ammonia concentration can be an indication of organic matter contamination. The total ammonia concentration obtained from the research ranged from 0.0791 to $0.2001 \mathrm{mg} / \mathrm{L}$ with the lowest concentration in treatment $\mathrm{C}$ in measurement on the $10^{\text {th }}$ day nurture while the highest concentration was obtained in treatment $\mathrm{A}$ in the measurement on the $20^{\text {th }}$ day.

In general, all fluctuations in ammonia levels had the same pattern (Figure 2) which was caused by the accumulation of excretions of fish and phytoplankton metabolism, so that it can kill a few cultivated fish. Toxin character of ammonia is associated with concentrations of non-ionized forms $\left(\mathrm{NH}_{3}\right)$. These toxic properties will be high in environments with low temperatures and high $\mathrm{pH}$ (Brigden and Stringer, 2000). An increase in $\mathrm{pH}$ of water will cause the percentage of $\mathrm{NH}_{3}$ in water to be higher (Hargreaves and Tucker 2004). The increase in ammonia in the blood and tissues will cause physiological damage in animals and changes in blood $\mathrm{pH}$ and intercellular. This will affect membrane stability and reaction of catalyst enzymes, various metabolic processes, especially in the brain and nerves (Colt and Amstrong 1981).

On the 30th day, the levels of ammonia in treatment B and $\mathrm{C}$ experienced a decrease close to the threshold, the value at treatment A was still above the limit. According to Popma and Lovshin (1996), $0.2 \mathrm{mg} / \mathrm{L}$ ammonia levels can cause death in fish. This decrease in ammonia levels is affected by the nitrification process that converts ammonia to nitrite; this is proven by increasing nitrite levels at the same measurement time (Figure 2). Ammonia is oxidized into nitrite $\left(\mathrm{NO}_{2}\right)$ and then into nitrate $\left(\mathrm{NO}_{3}\right)$ through nitrifying bacteria were grown on suspended organic matter. The bacteria remove the organic matter from the culture system by using it as food, while the bacteria themselves can be used as natural food for tilapia and carp (El-Sayed 2006).

\section{Nitrite}

In the nitrogen cycle, nitrite $\left(\mathrm{NO}_{2}\right)$ is known as the intermediate product at the process of bacterial nitrification and denitrification. It is usually found in very small amounts in natural waters (Kroupova et al. 2005). Nitrite is highly toxic to fish, including tilapia, because it disturbs the physiological functions of the fish and leads to growth retardation (El-Sayed 2006). Nitrite concentration obtained from the study ranged from $0.0018-0.0349 \mathrm{mg} / \mathrm{L}$ with the lowest concentration was in treatment $\mathrm{C}$ which was measured on 20th day while the highest concentration was obtained in treatment $\mathrm{B}$ in the measurement at the beginning of nurture.

There was a decrease in levels nitrite on the 10th and 20th day in all treatments (Figure 2), the decrease in nitrite content was closely related to the process of decomposing nitrite to nitrate in the process of nitrification, then on the 30th and 40th day there was a significant increase in all treatments due to the nitrification process which was breaking down ammonia to nitrite, but this increase did not exceed the nitrite tolerance limit for tilapia aquaculture ponds (Setiadi et al..2018). Nitrite in treatments A and B was higher than that in treatment $\mathrm{C}$ due to different $\mathrm{pH}$ values in the two treatments. Myrold (1999) explained that ammonia from fertilizer hydrolysis will be toxic to Nitrobacter but has no effect on Nitrosomonas, so nitrite accumulation will occur in soils with high $\mathrm{pH}$.

\section{Nitrate}

Nitrate $\left(\mathrm{NO}_{3}{ }^{-}\right)$is the main form of nitrogen that ready to absorb as the main source of nutrition for phytoplankton growth (Begum et al. 2003). Nitrate is relatively non-toxic to tilapia; however, prolonged exposure to high levels of nitrate may decrease immune response and induce mortality (El-Sayed 2006). Nitrate concentration obtained from the research ranged from $0.1195-0.4896 \mathrm{mg} / \mathrm{L}$ with the lowest concentration in treatment $\mathrm{A}$ in the measurement at 40th day while the highest concentration was obtained in treatment $\mathrm{C}$ in the measurement at the beginning of nurture.

There was a decrease in levels of nitrate (Figure 2) on the 10th and 20th day in all treatments, this decrease showed along with the decrease in nitrite concentration which means that ammonia decomposes into ammonium under aerobic conditions undergoing nitrification. In addition, the low value of nitrate can be affected by phytoplankton; low nitrate in water is probably related to the high algal productivity observed in the tanks. Phytoplankton absorbs nitrate from water for their growth (Masclaux et al. 2015). In addition, according to Nugroho et al. (2017), a decrease of nitrate concentration occurs in paddy rice fields due to its use by paddy rice as a source of nutrients for growth so as to prevent the occurrence of nitrate accumulation.

However, on 30th and 40th day there was no significant increase in all treatments. This was because the rate of change of nitrite to nitrate was hampered because of environmental factors such as temperature; in which the optimum temperature of nitrification was $20-28^{\circ} \mathrm{C}$ (Foch and Versatate 1977) while in this study, average temperature in the pond of RFCS was measured at range of $26-31^{\circ} \mathrm{C}$. Kumari et al. (2011) reported that the increases in temperature will be followed by decreasing of nitrification rate relating to the increasing of heterotrophic bacteria respiration in sediment. Nitrate content at 30th day was, respectively, $0.1426 \mathrm{mg} / \mathrm{L} ; 0.1901 \mathrm{mg} / \mathrm{L}$; and $0.1934 \mathrm{mg} / \mathrm{L}$ on treatment $\mathrm{A}, \mathrm{B}$, and $\mathrm{C}$.

\section{Survival rate of red tilapia}

Other parameters measured in addition to water quality are the survival rate of red tilapia. In Figure 3, it can be seen that during the nurture period there was a decrease in the level of survival rate recorded on the 30th day on all treatments, especially on treatment A. This was due to the significant increase in ammonia values in the 20th and 30th-day nurture exceeding the threshold. On the 40th day, there were still some death fish but fewer than that on 
the previous 10 days of nurture due to improved water quality. The survival rate of red tilapia in treatment $\mathrm{A}$ is lower due to an increase in the significant ammonia value that exceeds the threshold at $0.0125 \mathrm{mg} / \mathrm{L}$ (Swann 1997). Iqbal et al. (2012) stated that death in fish is usually caused by stress on environmental changes due to several things or treatments such as transport or transportation, another factor that influences the lives of these fish is the environment of its habitat.

The highest average value of survival rate was in treatment $\mathrm{C}$ as control, i.e. $96 \%$ and the lowest was in treatment A namely $91.33 \%$. The results of variance analysis showed that differences in the use of soil media in aquaculture ponds had no significant effect on the survival value of tilapia $(\mathrm{P}>0.05)$ (Figure 3$)$. The condition of the rice-fish culture system which contains a lot of ammonia causes the fish to become stressed and weak, and to have decreased in the body resistance and appetite, which will eventually inhibit the growth rate and can even cause death. According to Popma and Lovshin (1996), ammonia begins to decrease the appetite of tilapia at a concentration of $0.08 \mathrm{mg} / \mathrm{L}$, while at a concentration of 0.2 $\mathrm{mg} / \mathrm{L}$, tilapia will experience death.

The results of survival rates in this study were not different from the results obtained by Salsabila et al. (2013) stating that the survival rate of Larasati strain red tilapia that was nurtured with the rice-fish system reached
94.94\%. According to Basuki et al. (2015) Larasati tilapia cultivation in a rice-fish system with density of 5-10 fish $/ \mathrm{m}^{2}$ obtaining $80 \%$ survival rate.

Based on our study we can conclude that treatment using topsoil provides more stable water quality fluctuations, especially in the value of ammonia in the ricefish culture system. The difference in the ratio of the use of Ex-mining Land Soil and Top Soil has no significant effect on the level of survival of red tilapia Larasati (Oreochromis niloticus) at the end of the study. However, water quality in cultivation media will affect the growth of cultivated fish. The advice given is the application of rice-fish culture system on ex-mining land through the addition of topsoil with ratio $1: 1$.

\section{ACKNOWLEDGEMENTS}

This study was supported by PT. Semen Indonesia (Tbk.) in Tuban, Indonesia. In addition, financial support was provided by LPPM of Institute of Technology Sepuluh Nopember, Surabaya, Indonesia. We would also thank University of Ronggolawe as a research partner and for the help of students who helped in data collection and care of fish.

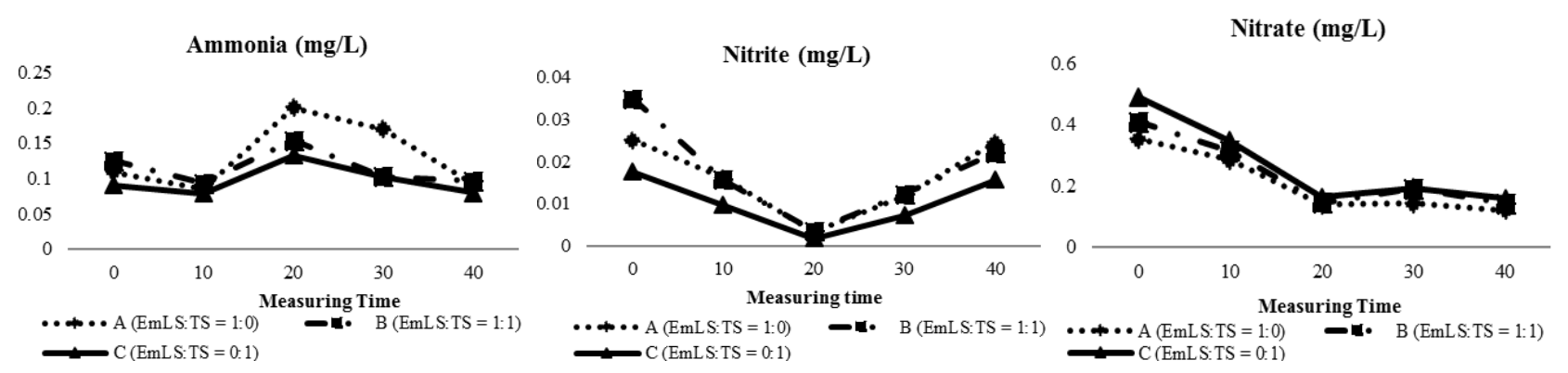

Figure 2. The average value of the RFCs nurture pond during the observation period $($ EmLS $=$ Ex-mining Land Soil and TS $=$ Top Soil)
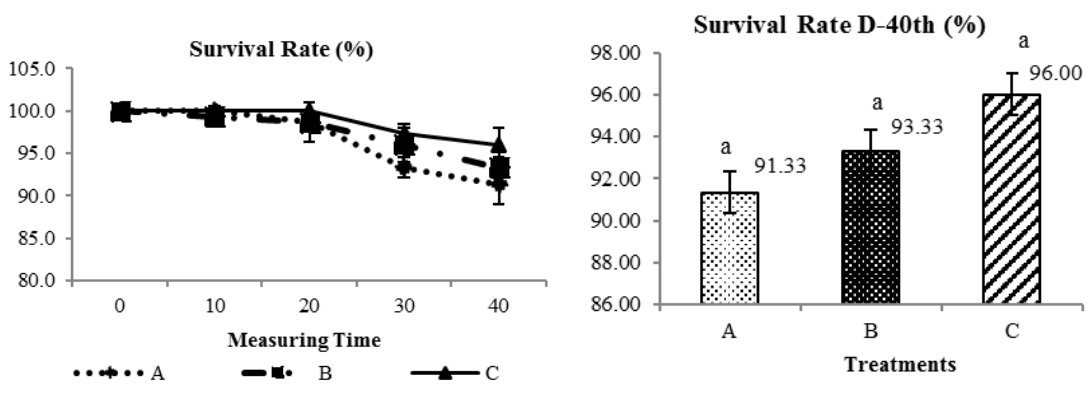

Figure 3. The average value of Red Tilapia survival rate at the end of observation period by using rice-fish culture system. Note: A (EmLS:TS=1:0), B (EmLS:TS =1:1), C (EmLS:TS =0:1) 


\section{REFERENCES}

Abbasi A, Annor FO, Van de Giesen N. 2016. Investigation of temperature dynamics in small and shallow reservoirs, case study: Lake Binaba, Upper East Region of Ghana. Water 8 (3): 84; DOI: $10.3390 / w 8030084$

Basuki F, Hastuti S, Subandiyono, Hadie W. 2013. Growth performance of Larasati Tilapia (Oreochromis niloticus) which is maintained by bioflok technology. Proceeding of Fish National Conference 8th, Diponegoro University, Semarang. [Indonesian]

Begum M, Hossain MY, Wahab MA, Kohinoor AHM. 2003. Effects of iso-phosphorous fertilizers on water quality and biological productivity in fish pond. $\mathrm{J}$ Aquacult Trop 18: 1-2

Boyd ACE, Wood CW, Thunjai T. 2002. Aquaculture Pond Bottom Soil Quality Management (A Manual). Pond Dynamics/Aquaculture Collaborative Research Support Program (PD/ACRSP) Oregon State University. United States Agency for International Development (USAID), Oregon, USA

Brigden K, Stringer R. 2000. Ammonia and Urea Production: Incidents of Ammonia Release From The Profertil Urea and Ammonia Facility, Bahia Blanca, Argentina. Greenpeace Research Laboratories, Departement of Biological Science University of Exeter, UK.

Clarke A, Johnston NM. 1999. Scaling of metabolic rate with body mass and temperature in teleost fish. J Anim Ecol 68: 893-905.

Colt JE, Amstrong DA. 1981. Nitrogen toxicity to crustacea, fish and Mollusca. Bio-eng Symp 1: 34-47.

El-Sayed AFM, Kawanna M. 2008. Short Communication: Optimum water temperature boosts the growth performance of Nile tilapia (Oreochromis niloticus) fry reared in a recycling system. Aquacult Res 39: 670-672

El-Sayed AFM. 2006. Tilapia Culture. CABI Publishing. Cambridge.

El-Sherif MS, El-Feky AMI. 2009. Performance of Nile tilapia (Oreochromis niloticus) fingerlings I. effect of $\mathrm{pH}$. Intl J Agricult Biol 11 (3): 297-300.

Foch DD, Versatate W. 1977. Biochemical ecology of nitrification and denitrification. Adv Microbiol Ecol 1: 135-214.

Goddard S. 1996. Feed Management in Intensive Aquaculture. Chapman and Hall. New York.

Hargreaves JA., Tucker CS. 2004. Managing Ammonia in Fish Ponds. South Regional Aquaculture System (SRAC) Publication No. 4603, USDA, Washington, DC

Hutagalung HP, Rozak. 1997. Methods of Analysis of Seawater, Sediment and Biota. P3O-LIPI. Jakarta. [Indonesian]

Iqbal KJ, Qureshi NA, Ashraf M, Rehman MHU, Khan N, Javid A, Abbas F, Mushtaq MMH, Rasool F, Majeed H. 2012. Effect of different salinity levels on growth and survival of nile tilapia (Oreochromis niloticus). J Anim Plant Sci 22 (4): 919-922.

Jean-Renaud A, Emmanuel AN, Yves BK, François AJBL, Cyrille KN. 2016. Evaluation of Performance of Nile Tilapia (Oreochromis niloticus) Crop in Rice-Fish Ponds. Entomol Zool Stud 4 (1): 91-97.

Kausar R, Salim M. 2006. Effect of water temperature on the growth performance and feed conversion Ratio of Labeo rohita. Pakistan Vet J 26 (3): 105-108.
Kroupova H; Machova J., Svobodova Z. 2005. Nitrite influence on fish: a review. Vet Med 50 (11): 461-471.

Kumari V, Rathore G, Pandey AK, Chauhan UK, Lakra WS. 2011. Seasonal variations in abundance of nitrifying bacteria. J Environ Biol 32: 153-159.

Lucas JS; Southgate PC, Tucker CS. 2018. Aquaculture: Farming Aquatic Animals and Plants. 3rd ed. John Wiley \& Sons, New York.

Masclaux H, Tortajada S, Philippine O, Robin FX, Dupuy C. 2015. Planktonic food web structure and dynamic in freshwater marshes after a lock closing in early spring. Aquat Sci 77 (1): 115-128.

Myrold DD. 1999. Transformation of Nitrogen. In: Principles and Application of Soil Microbiology. Sylvia DM, Jeffry JF, Peter GH, David AZ. (eds.) Prentice Hal Anderson, JM dan Ingram, JS. 1989. Tropical Soil Biology and Fertility, A Handbook of Methods, Commonwealth Agricultural Bureau, Wallingford.

Nugroho HB, Basuki F, Wisnu AR. 2017. Effect of different stocking density toward growth rate of tilapia (Oreochromis niloticus Linn. 1758) in rice-fish farming system. J Aquacult Manag Technol 6 (2): 21-30.

Nwachukwu MA, Ojeaga K, Chinelo G. 2018. Critical issues of sustainability associated with quarry activities. Asp Mining Mineral Sci 1 (2): 1-8.

Parascita L, Sudiyanto A, Nusanto G. 2015. Reclamation plan for former clay mining land at Tlogowaru quarri PT. Semen Indonesia (Persero) Tbk. Tuban factory, East Java. Teknologi Pertambangan 1 (1): 1-4. [Indonesian]

Peraturan Pemerintah Republik Indonesia Nomor 82 Tentang Pengelolaan Kualitas Air dan Pengendalian Pencemaran Air. 2001. Baku Mutu Air Tawar. Perikanan dan Peternakan.

Peshkova G, Cherepovitsyn A, Tcvetkov P. 2016. Prospects of the environmental technologies implementation in the cement industry in Russia. Ecol Eng 14 (4): 17-24.

Popma TJ, Lovshin LL. 1996. World prospect for commercial production of tilapia. Research and Development Series No. 41. International Center for Aquaculture and Aquatic Environments, Departement of Fisheries and Allied Aquacultures Auburn University, Alabama.

Salsabila A, Basuki F, Hastuti S. 2013. Growth performance of different tilapia strains (Oreochromis niloticus) in rice-fish culture systems. Aquaculture Management and Technology 2 (4): 1-6.

Setiadi E, Widyastuti YR, Prihadi TH. 2018. Water quality, survival, and growth of red tilapia, Oreochromis niloticus cultured in aquaponics system. E3S Web of Conferences 47: 1-8.

Swann LD. 1997. A Fish Farmer's Guide to Understanding Water Quality, Aquaculture Extension Illinois, Purdue University, Indiana Sea Grant Program Fact Sheet AS-503, West Lafayette, IN.

Tsuruta T, Yamaguchi M, Abe S, Iguchi K. 2011. Effect of fish in ricefish culture on the rice yield. Fisheries Science 77: 95-106.

World Business Council for Sustainable Development (WBCSD). 2011. Guidelines on Quarry Rehabilitation. Atar Roto Presse SA. Switzerland. 